\title{
PHOTOCATALYTIC DEGRADATION OF FAST GREEN USING NANOSIZED $\mathrm{CeCrO}_{3}$
}

\author{
Indu Bhati*, Pinki B. Punjabi, Suresh C. Ameta \\ Photochemistry and Solar Energy Laboratory, Department of Chemistry, \\ M. L. Sukhadia University, Udaipur-313001Rajasthan, India \\ indu_0311@yahoo.co.in
}

\begin{abstract}
Fast green dye has been widely used in histology and cytology. It has been found to have tumorigenic effects in experimental animals, as well as mutagenic effects in both experimental animals and humans. Furthermore, in its undiluted form it poses risks of irritation of eyes, skin, digestive tract, and respiratory tract. For photocatalytic degradation of fast green dye the nano-sized bimetal ternary oxide $\left(\mathrm{CeCrO}_{3}\right)$ ultrafine powder has been prepared using microwave treatment. It has been characterized by XRD and SEM. The photocatalytic degradation of fast green dye was measured by visible absorption spectroscopy. To obtain the optimal conditions for the dye degradation, the effect of various experimental parameters, i.e. $\mathrm{pH}$, amount of photocatalyst, concentration of dye and light intensity on the rate of reaction was studied. A tentative mechanism for the photocatalytic degradation of fast green was proposed. Photocatalytic degradation of fast green dye followed a pseudo first-order kinetics. It was found that the dye degradation gave the best results at a pH of 7.5, and using a $70 \mathrm{~mW} \cdot \mathrm{cm}^{-2}$ light intensity with $0.05 \mathrm{~g}$ of nano-sized $\mathrm{CeCrO}_{3}$. At room temperature, the photocatalytic degradation rate constant of fast green dye was $k=4.41 \cdot 10^{-4} \mathrm{~s}^{-1}$.
\end{abstract}

Keywords: photocatalytic degradation; fast green; nanosized $\mathrm{CeCrO}_{3}$; visible absorption spectrometry.

\section{ФОТОКАТАЛИТИЧКО РАСПАЃАЊЕ НА МАЛАХИТНО ЗЕЛЕНО СО УПОТРЕБА НА НАНОЧЕСТИЧКИ ОД СеСКО}

Бојата малахитно зелено е многу користена во хистологијата и цитологијата. Утврдено е дека спречува развој на тумор кај експериментални животни, но и дека доведува до мутации кај експериментални животни и кај луѓе. Во нерастворена форма предизвикува надразнување на очите и на кожата, како и на дигестивниот и дишниот систем. За фотокаталитичкото распаѓање на бојата малахитно зелено, со помош на микробранов третман, подготвен е ултраспрашен образец од биметален тернарен оксид $\left(\mathrm{CeCrO}_{3}\right)$ со нанодимензии, кој е карактеризиран со XRD и SEM. Фотокаталитичкото распаѓање на малахитно зелената боја е следено со видлива апсорпциона спектрометрија. При определувањето на оптималните услови за распаѓње на бојата е проучуван ефектот на различни експериментални параметри ( $\mathrm{pH}$, уделот на фотокатализаторот, концентрацијата на бојата и интензитетот на светлина) врз брзината на реакцијата. На таков начин е предложен можен механизам за фотокаталитичко распаѓање на малахитно зелено кое пројавува кинетика од псевдопрв ред. Најдено е дека распаѓањето на бојата најдобро се одвива при рН од 7,5 и при интензитет на светлина од $70 \mathrm{mWcm}^{-2}$ со $0,05 \mathrm{~g}$ наночестички од $\mathrm{CeCrO}_{3}$. При собна температура, константата на брзина на фотокаталитичкото распаѓање на малахитно зелено изнесува $k=4.41 \cdot 10^{-4} \mathrm{~s}^{-1}$.

Клучни зборови: фотокаталитичко распаѓање; малахитно зелено; на $\mathrm{CeCrO}_{3}$ наночестички; видлива апсорпциона спектрометрија. 


\section{INTRODUCTION}

Every method of wastewater treatment has its own limitations. In this context, photocatalysis has been considered as an emerging technology for the treatment of wastewater, as the photocatalysts are able to degrade the undesirable organics dissolved in water completely. The photocatalytic process can mineralize the hazardous organic chemicals to carbon dioxide, water and simple ions [1]. Liqiang et al. [2] reviewed the photoluminescence performance of nano-sized semiconducting materials and its relationship with photocatalytic activity. Current research efforts in the area of nanocrystalline semiconducting oxides are driven to a great extent, by many such applications where such nanosized particles are expected to find a proper use. Such applications include novel optical, electrical, and mechanical devices, photovoltaic solar cells, light-emitting diodes, varistors, light catalysts, gas sensors, optoelectronic devices, optical switches, UV absorbers, nano-lasers, ion-insertion batteries, electrochromic devices, etc. [3]. Although, a number of methods are available for the preparation of nanosized metal oxides, microwave method can produce nanosized particles at relatively low cost, in shorter time with relatively inexpensive equipments. Microwave assisted syntheses of different nanoparticle oxides have been reported by various workers, i.e. $\mathrm{MnFe}_{2} \mathrm{O}_{4}$ [4], $\mathrm{CuO}$ [5], $\mathrm{Bi}_{2} \mathrm{WO}_{6}[6], \mathrm{Bi}_{2} \mathrm{O}_{3}[7]$ and $\mathrm{Co}_{3} \mathrm{O}_{4}[7]$. Nanosized oxides have proved their efficiency in photocatalytic degradation of dimethoate [8], azo dye [9], malachite green [10], organophosphorus compounds [11] and chloro-, fluoro-, bromocarbons and sulfur compounds [12].

Mittal et al. [13] tried batch and bulk removal of fast green FCF from wastewater by adsorption over de-oiled soya and bottom ash, which are agricultural waste and power plants waste, respectively. Various researchers investigated the degradation of fast green dye using Azadirachta indica (neem) leaf powder [14], electrogenerated Fenton reagent at carbon-felt cathode [15], aqueous suspension of titanium dioxide under a variety of conditions [16,17] and $\mathrm{ZnO}[18]$ as photocatalysts.

In a literature survey, no attention was found to have been paid to the photocatalytic degradation of fast green dye using nanosized $\mathrm{CeCrO}_{3}$. As more active sites are available in small sized particles, due to higher surface area, they show higher efficiency. In nanoparticles, the quantum size effect and low electron-hole recombination also help in enhancing the efficiency of photocatalysts. Therefore, in the present investigation an attempt was made to carry out photochemical degradation of fast green dye in a heterogeneous medium.

\section{EXPERIMENTAL}

\subsection{Chemicals and measurements}

Fast green (ethyl-[4-[[4-[ethyl-[(3-sulphophenyl)methyl]amino]phenyl]-(4-hydroxy-2 -sulphophenyl)methylidene]-1-cyclohexa-2,5 -dienylidene]-[(3-sulphophenyl)methyl]azanium) (Figure 1), sodium hydroxide, sulphuric acid, acetic acid and other chemicals employed in the present study were of analytical grade grade. Fast green $(\mathrm{CDH})$ dye was used as a model system to investigate the photocatalytic degradation by synthesized $\mathrm{CeCrO}_{3}$. Fast green is also known as food green $3, \mathrm{FD} \& \mathrm{C}$ green No. 3, green 1724, solid green FCF, (C. I. 42053) [19]. Its molecular formula is $\mathrm{C}_{37} \mathrm{H}_{34} \mathrm{~N}_{2} \mathrm{O}_{10} \mathrm{~S}_{3} \mathrm{Na}_{2}$, and its molar mass is $808.85 \mathrm{~g} / \mathrm{mol}$. $1.0 \cdot 10^{-3} \mathrm{M}$ solution of fast green $(0.202 \mathrm{~g}$ fast green in 250 $\mathrm{mL}$ water) was prepared in volumetric flask with doubly distilled water and stored as a stock solution. The photocatalytic degradation of fast green was observed by taking dye solution of $1 \cdot 10^{-5} \mathrm{M}$ and $0.05 \mathrm{~g}$ of $\mathrm{CeCrO}_{3}$. Irradiation was carried out keeping the whole assembly exposed to a $200 \mathrm{~W}$ tungsten lamp (Philips, light intensity $=70.0 \mathrm{~mW} \cdot \mathrm{cm}^{-2}$ ). The intensity of light was measured with the help of a solarimeter (SM CEL 201). The $\mathrm{pH}$ of the solution was measured by the digital $\mathrm{pH}$ meter (Systronics Model 335). The desired $\mathrm{pH}$ of solution was adjusted by the addition of previously standardized $0.1 \mathrm{~N}$ sul- 
<smiles>CCN(Cc1cccc(S(=O)(=O)O[Na])c1)c1ccc(C(=C2C=CC(=[N+](CC)Cc3cccc(S(=O)(=O)[O-])c3)C=C2)c2ccc(O)cc2S(=O)(=O)O[Na])cc1</smiles>

Fig. 1. Molecular structure of fast green dye

phuric acid and $0.1 \mathrm{~N}$ sodium hydroxide solutions. The optical density (OD) was measured by visible absorption spectroscopy (Systronics Model 106), under the necessary conditions that the sample solutions are free from photocatalyst particles and impurity.

\subsection{Synthesis of the precursor}

A $0.1 \mathrm{M}$ aqueous solution of chromium sulphate $\mathrm{Cr}_{4}\left(\mathrm{SO}_{4}\right)_{5}(\mathrm{OH})_{2}$ and a $0.1 \mathrm{M}$ aqueous solution of cerric sulphate tetrahydrate were mixed at room temperature. According to Bae et al. [20] the size of particles was dictated by the molar ratio of starting materials. This mixture was quickly fed with a $6 \mathrm{M}$ aqueous sodium hydroxide to maintain the $\mathrm{pH}$ at 9 . By the repetition of this process at different $\mathrm{pH}(7,8,9$ and 10$)$, it was found that the hydroxides precipitated more at $\mathrm{pH} 9$ ). The latter mixture was continuously stirred for $10 \mathrm{~h}$ at room temperature for completion of precipitation.

\subsection{Microwave treatment}

The precipitate was kept in an oven at $60{ }^{\circ} \mathrm{C}$ for drying overnight. Then, the dried precipitate was grounded with a pestle in a mortar. Grounded material was irradiated in domestic microwave for 6 min. Conventional method for synthesis of bimetal ternary oxide is a very time and energy-consuming process while microwave heating, instead of furnace heating [21], provides a method, which takes only few minutes leading to an energy saving and eco-friendly approach. It is to be supposed that rapid and intense heating by microwaves did not give sufficient time to the particles for aggregation on nucleus. This resulted in formation of smallsized, uniform particles. The synthesized nanosized bimetal oxide was finally washed with dil. acetic acid to remove $\mathrm{CeO}_{2}$ and $\mathrm{CrO}_{2}$.

\subsection{Photocatalytic degradation}

The photocatalytic degradation of fast green dye using nanosized $\mathrm{CeCrO}_{3}$ as photocatalyst under visible light was investigated by visible absorption spectroscopy, and most kinetic measurements were performed at room temperature $(300 \mathrm{~K})$. The concentration of dye in the form of optical density before and after photocatalytic degradation was measured at $620 \mathrm{~nm}$ ( $\lambda_{\text {max }}$ value obtained for fast green dye). A $200 \mathrm{~W}$ tungsten lamp (Philips) was used as the visible light source. A cutoff filter was placed outside the beaker (Pyrex) to completely remove any thermal radiation just to ensure illumination by visible light. The progress of the photocatalytic reaction was observed by taking optical density at regular time intervals.

The change in absorbance at the $\lambda_{\text {max }}$ value versus the irradiation time was measured. A typical run is presented in Figure 2. It was observed that the optical density (OD) of fast green solution decreased in presence of the photocatalyst and light. The plot of log OD versus time was linear and hence, this reaction followed pseudo first-order kinetics. The rate constant $(k)$ for this reaction was determined from the expression $k=-2.303 \cdot$ slope. A value of $k=4.41 \cdot 10^{-4} \mathrm{~s}^{-1}$ was determined for this reaction in the optimum conditions. 


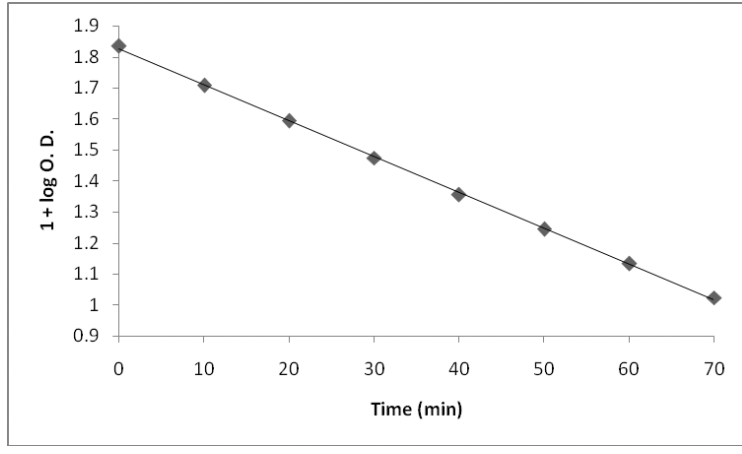

[Fast green $]=1.00 \cdot 10^{-5} \mathrm{M} ;\left[\mathrm{CeCrO}_{3}\right]=0.05 \mathrm{~g}$,

Light intensity $=70.0 \mathrm{~mW} \cdot \mathrm{cm}^{-2} ; \mathrm{pH}=7.5$, Room temperature.

Fig. 2. A typical run for degradation of fast green

\section{RESULTS AND DISCUSSION}

\subsection{Characterization}

The synthesized nanosized $\mathrm{CeCrO}_{3}$ was characterized by X-ray powder diffraction method and scanning electron microscopy (SEM). Figure 3 presents the X-ray diffraction patterns of $\mathrm{CeCrO}_{3}$. The graph has been plotted between intensity (cycles per second) and $2 \theta$ values (in degree), for general conditions $2 \theta$ value ranges from $20^{\circ}-80^{\circ}$. Figure 4 represents the SEM image of $\mathrm{CeCrO}_{3}$. It is clear from the picture that the size of a cluster was $20 \mu \mathrm{m}$ at $600 \times$ magnification, whereas it was $2 \mu \mathrm{m}$ at $7500 \times$ magnification. It was performed on JEOLJSM 5600 operated at 0.5 to $30 \mathrm{KV}$, whose resolution power is up to $3.5 \mathrm{~nm}$. The numberweighted average particle size was found to be comparable with the volume-weighted mean size obtained from the broadening of the X-ray diffraction lines (Scherer formula).

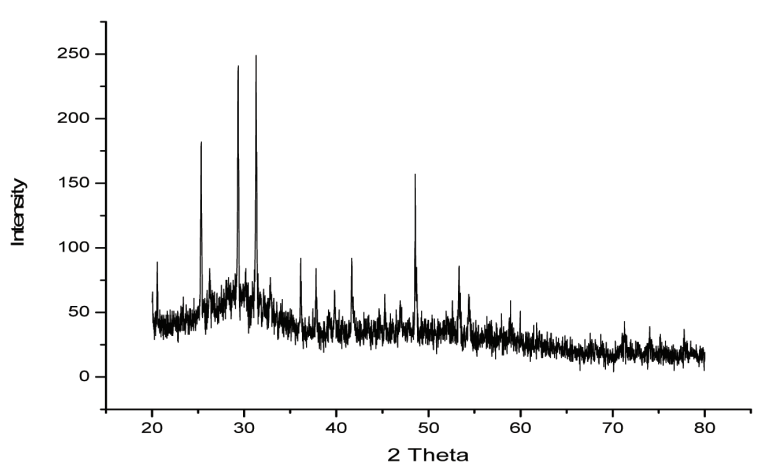

Fig. 3. X-ray powder diffraction of $\mathrm{CeCrO}_{3}$

$$
\mathrm{D}=\frac{\mathrm{K} \cdot \lambda}{\mathrm{B} \cdot \cos \theta}
$$

where $D$ is the crystallite size and its calculated value is $93.12 \mathrm{~nm} ; K$ is a constant depending upon crystal structure and taken $0.99 ; \lambda$ is the wavelength used in XRD $\left(5.4 \cdot 10^{-10}\right.$ $\mathrm{m}) ; \beta$ is the full width of half-maximum (FWHM) and $\theta$ is the Bragg's angle in radian.

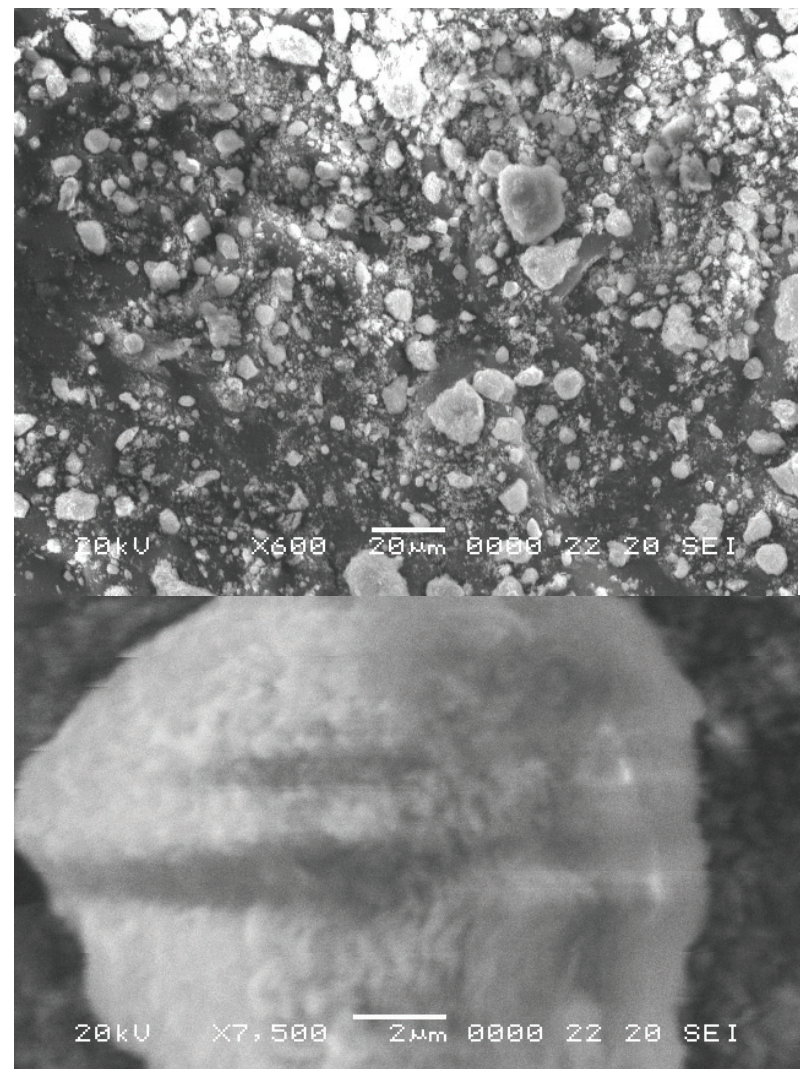

Fig. 4. Scanning electron microscopy images of microwave synthesized $\mathrm{CeCrO}_{3}$

\subsection{Effect of $p H$}

The effect of $\mathrm{pH}$ on photocatalytic degradation was investigated in the range $4.5-8$. The results are reported in Table 1 .

It is evident from the data that the degradation rate of fast green increases with increasing $\mathrm{pH}$ of solution up to 7.5 and above this value of $\mathrm{pH}$, the rate of photocatalytic degradation of fast green starts decreasing. It may be explained on the basis that at low $\mathrm{pH}$, the anionic dye (Figure 1) was attracted by positively charged surface of photocatalyst, but 
after a certain limit, further increase in $\mathrm{pH}$ turned surface of photocatalyst as negatively charged. Due to presence of lone pairs on two nitrogen atoms, fast green (Figure 1) seems to face a force of repulsion from negatively charged surface of the photocatalyst, which results into a decreasing rate of reaction.

Ta b le 1

\section{Effect of $p H$ on photolytic degradation of fast green}

\begin{tabular}{cc}
\hline \hline $\mathrm{pH}$ & $k \cdot 10^{4}\left(\mathrm{~s}^{-1}\right)$ \\
\hline 4.5 & 1.35 \\
5 & 1.43 \\
5.5 & 1.91 \\
6 & 2.11 \\
6.5 & 3.04 \\
7 & 3.66 \\
7.5 & $\mathbf{4 . 4 1}$ \\
8 & 2.96 \\
\hline \hline
\end{tabular}

$[$ Fast green $]=1 \cdot 10^{-5} \mathrm{M}$; Light intensity $=70.0 \mathrm{~mW} \cdot \mathrm{cm}^{-2}$; $\left[\mathrm{CeCrO}_{3}\right]=0.05 \mathrm{~g}$ : Room temperature.

\subsection{Effect of concentration of fast green}

The concentration of dye was varied from $0.33 \cdot 10^{-5} \mathrm{M}$ to $1.5 \cdot 10^{-5} \mathrm{M}$. The results are reported in Table 2.

It has been observed that the rate of photocatalytic degradation increases with increase in the concentration of the dye up to $1 \cdot 10^{-5} \mathrm{M}$. This may be due to the fact that as the concentration of the fast green was increased, more dye molecules were available for excitation and consecutive degradation. Hence, an increase in the rate was observed. The rate of photocatalytic degradation was found to decrease with further increase in the concentration of dye. This may be attributed to the fact that the dye started acting as a filter for the incident light and it does not permit the desired light intensity to reach the photocatalyst surface in a limited time domain; thus, decreasing the rate of photocatalytic degradation of fast green.
Table 2

Effect of fast green concentration on photolytic degradation

\begin{tabular}{cc}
\hline \hline [Fast green] $\cdot 10^{5} \mathrm{M}$ & $k \cdot 10^{4}\left(\mathrm{~s}^{-1}\right)$ \\
\hline 0.33 & 1.68 \\
0.5 & 2.22 \\
0.66 & 2.72 \\
0.83 & 3.6 \\
$\mathbf{1}$ & $\mathbf{4 . 4 1}$ \\
1.16 & 3.9 \\
1.33 & 2.97 \\
1.5 & 2.49 \\
\hline \hline
\end{tabular}

$\mathrm{pH}=7.5$; Light intensity $=70.0 \mathrm{~mW} \cdot \mathrm{cm}^{-2}$;

$\left[\mathrm{CeCrO}_{3}\right]=0.05 \mathrm{~g}$; Room temperature.

\subsection{Effect of the amount of photocatalyst}

The effect of the amount of photocatalyst is also likely to affect the process of dye degradation and therefore, different amounts of photocatalyst were used. The results are reported in Table 3.

Ta b le 3

Effect of the amount of photocatalyst on photolytic degradation

\begin{tabular}{cc}
\hline \hline $\mathrm{CeCrO}_{3}(\mathrm{~g})$ & $\mathrm{k} \cdot 10^{4}\left(\mathrm{~s}^{-1}\right)$ \\
\hline 0.01 & 2.27 \\
0.02 & 2.7 \\
0.03 & 2.89 \\
0.04 & 4.12 \\
$\mathbf{0 . 0 5}$ & $\mathbf{4 . 4 1}$ \\
0.06 & 4.31 \\
0.07 & 4.27 \\
0.08 & 4.24 \\
\hline \hline
\end{tabular}

$\mathrm{pH}=7.5 ;[$ Fast Green $]=1 \cdot 10^{-5} \mathrm{M}$;

Light intensity $=70.0 \mathrm{~mW} \cdot \mathrm{cm}^{-2}$; Room temperature.

It has been observed that as the amount of photocatalyst was increased, the rate of photodegradation of fast green also increased as well 
as the number of active sites. But ultimately the rate became almost constant after adding a certain amount $(0.05 \mathrm{~g})$ of photocatalyst. This may be due to the fact that, after a certain limit, the increase in amount of $\mathrm{CeCrO}_{3}$ did not increase the exposed surface area (active sites) of the photocatalyst. It only increased the thickness of the layer, as the bottom of the reaction vessel was covered by the photocatalyst. It may be considered that a kind of saturation point was reached, and that, after this saturation point no effect of amount of photocatalyst was observed. This hypothesis was also confirmed by using reaction vessels of different dimensions. As the bottom area of the vessel increased, the photocatalyst exposed area also increased, hence, the rate of photocatalytic degradation increased. In the present work, beakers of the same size were also used for a whole experiment and, after a maximum exposure to photocatalyst, further addition of photocatalyst only increased the layer thickness, but did not contribute to increase the photocatalytic degradation rate.

\subsection{Effect of light intensity}

The effect of the variation of the light intensity on the rate was also investigated and the observations are represented in Figure 5.

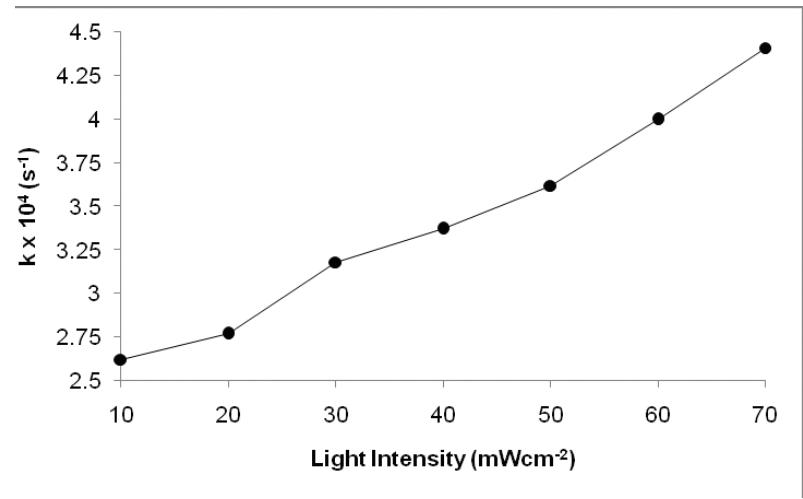

Fig. 5. Effect of light Intensity on photolytic degradation

The data indicate that the degradation action was accelerated as the intensity of light was increased, because any increase in the light intensity increases the number of photons striking per unit time per unit area of the photocatalyst powder. An almost linear behaviour between light intensity and the rate of reaction has been observed. However, higher intensities were avoided due to thermal effects.

\subsection{Tentative mechanism of fast green photodegradation}

On the basis of our experimental observations, a tentative mechanism for photocatalytic degradation (mineralization) of fast green may be proposed as:

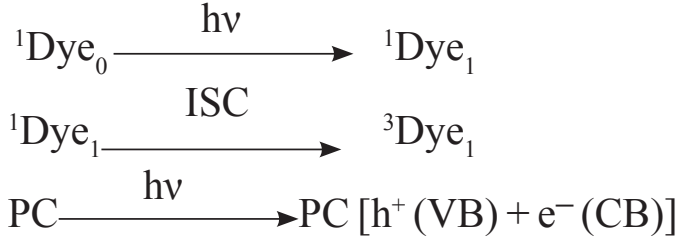

${ }^{3} \mathrm{Dye}_{1}+\mathrm{e}^{-\longrightarrow}{ }^{3} \mathrm{Dye}_{1}^{-}$(Leuco form)

${ }^{3} \mathrm{Dye}_{1}^{-}$(Leuco form) $\rightarrow$ Colorless photoproducts $(5)$

In the reaction, dye molecules absorb radiations of suitable wavelength and give rise to the singlet excited state (1). Then it may undergo an intersystem crossing (ISC) process to yield the more stable triplet excited state of the dye (2). Photocatalyst (PC) also utilizes the radiant energy to excite its electron from the valence band (VB) to the conduction band (CB), thus, leaving behind a hole $\left(\mathrm{h}^{+}\right)$in the VB (3). The electron present in the $\mathrm{CB}$ may be utilized to reduce the dye triplet excited state into its leuco form (4), which ultimately degrades to photoproducts (5). Another possible variant of this tentative mechanism would be the reduction of the dye excited singlet state $\left({ }^{1}\right.$ Dye $\left._{1}\right)$. The absence of role of hydroxyl radicals in this photocatalytic reaction was also confirmed by the fact that the reaction rate remained almost unaffected in the presence of the hydroxyl radical scavenger, propan-2-ol.

\section{CONCLUSION}

The nanosized photocatalyst $\mathrm{CeCrO}_{3}$ has been synthesized using microwave irradiation, 
which provides an ecologically friendly, rapid and intense heating instead of the time-consuming conventional heating. Due to the rapid and intense heating by microwave components there is not sufficient time to form aggregates at a single nucleus and ion, thus resulting into small-sized, uniform particles. Bimetallic ternary oxides with one or more transition metals are colored, hence permitting to utilize the broad visible spectrum of solar radiations. An advantage of heterogeneous photocatalysts (PC) for potential application is that PC are easily separable after the reaction and, therefore, they may further reduce the pollution of water. Moreover, heterogeneous PC are reusable with almost the same efficiency. In particular, $\mathrm{CeCrO}_{3}$ shows an excellent efficiency for the photocatalytic degradation of fast green dye. Also the discoloration of water would facilitate the recycling of water, which is, nowadays, a very demanding feature.

Acknowledgement: Authors are thankful to $\mathrm{Mr}$. Vinay and Mr. S. Bhardwaj, DST-UGC-CSR, Indore for providing the SEM and XRD facilities.

\section{REFERENCES}

[1] S. Ahmed and D. F. Ollis, Solar Photo-assisted catalytic decomposition of the chlorinated hydrocarbons trichloroethylene and trichloromethane, Sol. Ener., 32, 597-601 (1984).

[2] J. Liqiang, Q. Yichun, W. Baiqi, L. Shudan, J. Baojiang, Y. Libin, F. Wei, F. Honggang and S. Jiazhong, Review of photoluminescence performance of nano-sized semiconductor materials and its relationships with photocatalytic activity, Sol. En. Mater. Sol. Cells., 90, 1773-1787 (2006).

[3] A. S. Edelstein and R. C. Cammarata, Nanomaterials, Synthesis, Properties and Applications, Eds. Institute of Physics Publishing, Bristol 1996.

[4] W. W. Wang, Microwave-induced polyol-process synthesis of $\mathrm{M}^{\mathrm{II}} \mathrm{Fe}_{2} \mathrm{O}_{4}(\mathrm{M}=\mathrm{Mn}, \mathrm{Co})$ nanoparticles and magnetic property, Mater. Chem. Phy., 108 (2-3), 227-231 (2008).

[5] D. Keyson, D. P. Volanti, L. S. Cavalcante, A. Z. Simoes, J. A. Varela and E. Longo, CuO urchinnanostructures synthesized from a domestic hydrothermal microwave method, Mater. Res. Bull., 43

\section{(3), 771-775 (2008).}

[6] L. Wu, J. Bi, Z. Li, X. Wang and X. Fu, Rapid preparation of $\mathrm{Bi}_{2} \mathrm{WO}_{6}$ photocatalyst with nanosheet morphology via microwave-assisted solvothermal synthesis, Cat. Tod., 131, 15-20 (2008).

[7] R. Rajgopal, J. Mona, R. S. Joshee, S. N. Kale, S. Pradhan, A. B. Gaikwad and V. Ravi, $\mathrm{La}_{0.67} \mathrm{Ce}_{0.03} \mathrm{Sr}_{0.3} \mathrm{MnO}_{3}$-coupled microwave assisted ultra-fast synthesis of nanocrystalline Cobalt oxide and Bismuth oxide, Mater. Lett., 62 (10-11), 1511-1513 (2008).

[8] J. Q. Chen, D. Wang, M. X. Zhu and C. J. Gao, Photocatalytic degradation of dimethoate using nanosized $\mathrm{TiO}_{2}$ powder, Desalination, 207 (1-3), 87-94 (2007).

[9] A. O. Ibhadon, G. M. Greenway and Y. Yue, Photocatalytic activity of surface modified $\mathrm{TiO}_{2} / \mathrm{RuO}_{2} /$ $\mathrm{SiO}_{2}$ nanoparticles for azo-dye degradation, Catal. Commun., 9 (1), 153-157 (2008).

[10] C. C. Chen, C. S. Lu, Y. C. Chung and J. L. Jan, UV light induced photodegradation of malachite green on $\mathrm{TiO}_{2}$ nanoparticles, J. Hazard. Mater., 141 (3), 520-528 (2007).

[11] S. Rajagopalan, O. Koper, S. Decker and K. J. Klabunde, Nanocrystalline metal oxides as destructive adsorbents for organophosphorus compounds at ambient temperatures, Che. Eur. J., 8 (11), 26022607 (2002).

[12] S. Decker, J. S. Klabunde, A. Kjaleel and K. J. Klabunde, Catalyzed Destructive Adsorption of Environmental Toxins with Nanocrystalline Metal Oxides. Fluoro-, Chloro-, Bromocarbons, Sulfur, and Organophosphorus Compounds, Environ. Sci. Technol., 36, 762-768 (2002).

[13] A. Mittal, D. Kaur and J. Mittal, Batch and bulk removal of a triarylmethane dye, Fast Green FCF, from wastewater by adsorption over waste materials, J. Hazard. Mater., 163 (2-3), 568-577 (2009).

[14] H. Tahir, U. Hammed, Q. Zahanzeb and M. Sultan, Removal of fast green dye (C.I. 42053) from an aqueous solution using Azadirachta indica leaf powder as a low-cost adsorbent, African J. Biotechnol., 7 (21), 3906-3911 (2008).

[15] I. Sires, E. Guivarch, N. Oturan, M. A. Oturan, Efficient removal of triphenylmethane dyes from aqueous medium by in situ electrogenerated Fenton's reagent at carbon-felt cathode, Chemosphere, 72, 592-600 (2008).

[16] Saquib, M., Abu Tariq, M., Faisal, M., Muneer, M., 
Photocatalytic degradation of two selected dye derivatives in aqueous suspensions of titanium dioxide, Desalination, 219, 301-311 (2008).

[17] Saquib, M., Muneer, M., Photocatalytic degradation of CI Acid Green 25 and CI Acid Red 88 in aqueous suspensions of titanium dioxide, Coloration Technol., 118, 307-315 (2002).

[18] S. Bhandari, J. Vardia, R. K. Malkani and S. C. Ameta, Effect of transition metal ions on photocatalytic activity of $\mathrm{ZnO}$ in bleaching of some dyes, Toxicol. Environ. Chem., 88 (1), 35 (2006).

[19] Fast Green FCF, http://en.wikipedia.org/wiki/Fast Green_FCF, accessed February, 2010.
[20] D. S. Bae, K. S. Han and J. H. Adair, Synthesis and microstructure of $\mathrm{Pd} / \mathrm{SiO}_{2}$ nanosized particles by reverse micelle and sol-gel processing, J. Mater. Chem., 12 (10), 3117-3120 (2002).

[21] B. M. Reddy, G. K. Reddy, A. Khan and I. Ganesh, Synthesis of monophasic $\mathrm{Ce}_{0.5} \mathrm{Zr}_{0.5} \mathrm{O}_{2}$ solid solution by microwave-induced combustion method, J. Mater. Sci., 42 (10), 3557-3563 (2007). 